\title{
Trucks at Roundabouts: A Synthesis Study
}

\author{
Pavan Kumar Chevuri \\ Department of Civil Engineering, St. Ann's College of Engineering and Technology, Chirala, India \\ Email: chpavankumar2016@gmail.com
}

How to cite this paper: Chevuri, P.K. (2018) Trucks at Roundabouts: A Synthesis Study. Journal of Transportation Technologies, 8, 65-74. https://doi.org/10.4236/jtts.2018.81004

Received: November 11, 2017

Accepted: January 7, 2018

Published: January 10, 2018

Copyright $\odot 2018$ by author and Scientific Research Publishing Inc. This work is licensed under the Creative Commons Attribution International License (CC BY 4.0).

http://creativecommons.org/licenses/by/4.0/

\begin{abstract}
Roundabouts in United States and other countries have been proved to be very successful, effective, and a safe traffic control treatment. Roundabouts in the context of regularly expected truck configuration have also been successful for effective roundabout designs; however, there are always some site specific issues for trucks accommodation at roundabouts. Therefore, there is a great need for an informational guide in the form of synthesis report for roundabout designs specific to unique trucking traffic activity. While there are not significant literatures and studies in this subject, there are few studies/reports spread out which address various issues in this subject area. This study attempts to synthesize the research and knowledge of truck accommodation at roundabouts by synthesizing various research studies, reports, and articles; various subject areas such as roundabout designs for trucking activity, roundabout designs and accommodation strategies for specialized trucking activity such as oversized trucks, truck safety at roundabouts, and motor carrier perspective of trucking at roundabouts have been analyzed and relevant knowledge has been synthesized. This synthesis can be useful o researchers, designers, planners, and decision makers to determine effective ways to address specific trucking related issues at a roundabout.
\end{abstract}

\section{Keywords}

Roundabouts and Trucks, Oversized Trucks, Rural Intersections, Trucking Issues at Intersections

\section{Introduction and Study Objective}

Roundabouts have been proved to be the safe and efficient form of intersection control. Several studies conducted have concluded that implementing roundabouts as intersection control have reduced all traffic crashes by $40 \%$, and injury crashes by $80 \%$ [1] [2]. Further, studies conducted have proved that roundabouts are comfortable to be traversed for trucks, and access to businesses has not 
impacted much with the presence of roundabouts [3] [4] [5]. Some of the advantages of roundabouts over other type of intersection control include: increased safety performance, decreased vehicle delays and queue lengths, better speed management at intersections, and better aesthetic appearance with possibility for community enhancement features [6]. While roundabouts have been operational in other countries for many years, their existence and operations in United States have only began in the recent past and they are growing at an accelerated rate.

While roundabouts have been operationally very effective for regular traffic and trucks, specific issues have been identified for trucks using roundabouts including accommodation issues, safety issues, design issues, etc. There has been significant research about roundabout safety and operation performance; however, there are only very few studies addressing various concerns of trucks using roundabouts in different studies or reports. This study attempts to synthesize the trucks operation, trucks and oversized trucks accommodation, safety concerns and countermeasures, and truck driver perspectives of trucks using roundabouts. This synthesis can be useful to researchers, designers, planners, and decision makers to gather information needed relating to roundabouts in the context of trucks or oversized trucks.

The objective of the study is to focus on trucking activity at roundabouts in United States, identify various issues along with gathering and synthesizing their countermeasures. Studies and research in United States and in other counties will be considered for this purpose.

\section{Designing Roundabouts for Trucks}

Traditionally roundabouts were designed in compact circular area to attain a curved geometry that forces vehicles using roundabout to slow down and therefore can promote safety benefits to vehicles using the intersection due to low speeds at the intersection. While the curved geometry can force the passenger cars to traverse at lower speeds, they can be very compact for trucks or other larger vehicles which may likely use the roundabouts occasionally.

The largest vehicle that is likely to use the intersection/roundabout is called as a design vehicle and its accommodation needs to be considered to the roundabout geometry while designing any kind of intersection treatment. However, if the roundabout's inscribed circular diameter and geometry is increased to accommodate the design vehicles, the roundabout's geometry, curvature, and lane width can encourage passenger car users to travel at higher speeds causing safety concerns, which negates the basic safety benefits of installing a roundabout. Therefore, to keep the roundabout geometry tight and also to accommodate design vehicle (mostly a truck), truck aprons are constructed for the outer edge of center island for bigger vehicles to traverse when additional space is needed. Further, these truck aprons are raised by two to four inches above the ground to discourage passenger vehicles from using them so the roundabout still provides 
curves and geometry to promote slower speeds for the traffic [6]. Before planning a roundabout, an engineer should determine the design vehicle and conduct a swept path analysis of the design vehicle at a roundabout using a CAD-based software to determine various geometric features of the roundabouts such as truck apron width, circulatory roadway width, entry roadway width, etc.; typically design vehicle turning requirements determines various roundabout dimensions [6]. WB-50 (shown in Figure 1) are commonly the design vehicles for urban collectors and arterials, and larger trucks such as WB-67 (shown in Figure 1) may be used as design vehicles for intersections on intersections on interstate freeway or state highway systems [6].

Truck aprons must be constructed with different material than the pavement surface so it can be differentiated from the circulatory roadway [6]. Also, care must be taken for the truck aprons not to be constructed aesthetically pleasing, because truck drivers can mistake them as landscape area of the roundabout and can avoid using them [7]. Truck apron width is determined by conducting the swept path analysis of design vehicle at the roundabout design using a CAD-based swept path analysis. The width of truck aprons is generally $3 \mathrm{ft}-15 \mathrm{ft}$ and can have a cross slope of $1 \%$ to $2 \%$ away from the center island [6]. Figure 2 illustrates truck using a truck apron at a roundabout which is elevated above the road level.

Inscribed circle diameter is a critical geometry to be determined for designing and constructing a roundabout based on the location, type of roundabout

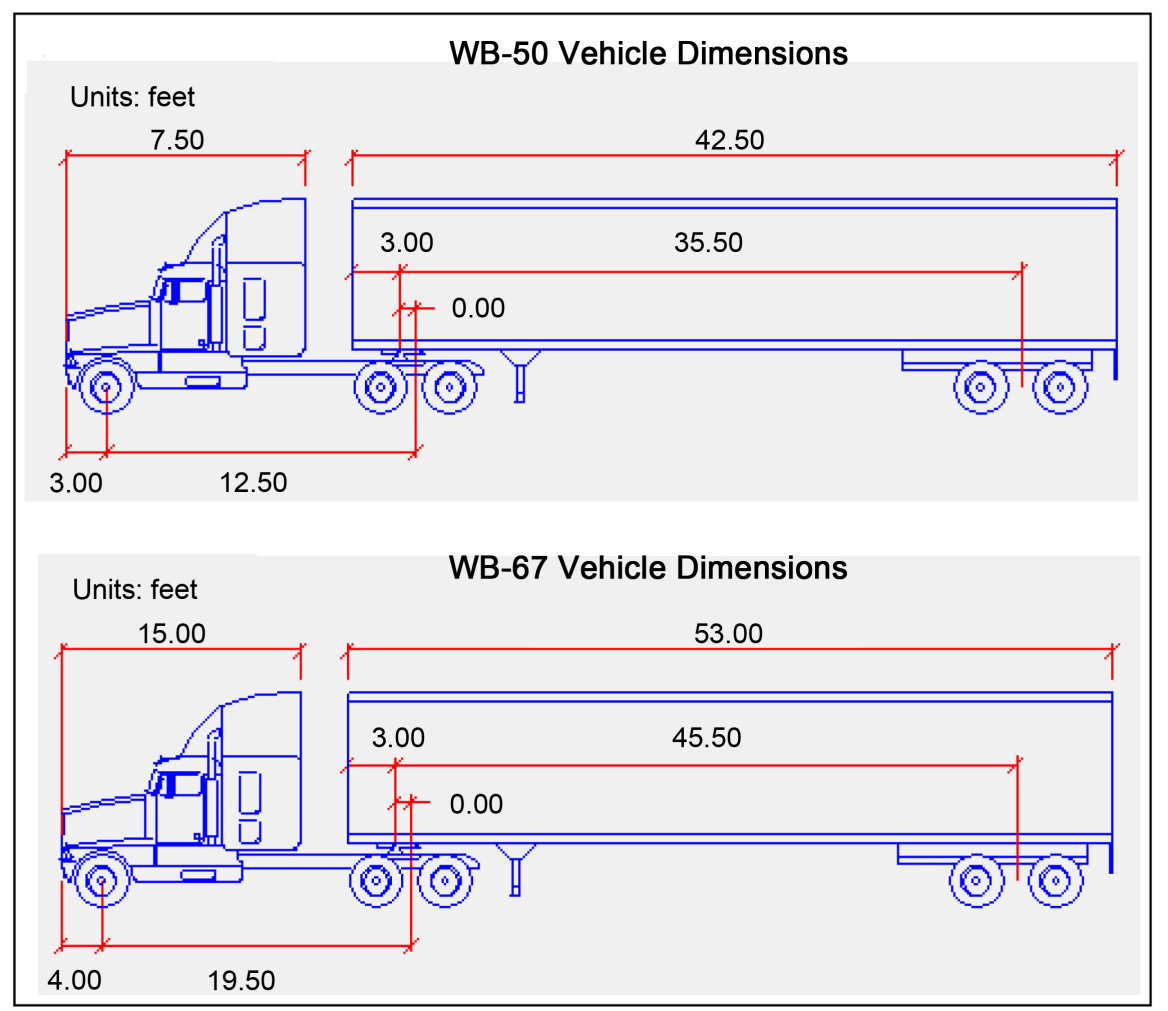

Figure 1. WB-50 and WB-67 vehicle configurations. 
needed, and design vehicle. Inscribed circle diameter also governs design aspects such as speed control, visibility for center island, and accommodation of design vehicles [6]. The second edition of roundabout guide synthesized the inscribed circle diameter ranges for roundabouts based on their type and design vehicles (shown in Table 1). These inscribed circle diameters can be used for designing a roundabout based on the design vehicle and iterations can be conducted to finalize the roundabout design based on location specific requirements.

\section{Accommodation of Large Trucks and Oversized Trucks at Roundabouts}

As the use of roundabouts in rural areas, freeway ramps, and highway intersections have been increasing, one prominent issue identified at roundabouts is accommodating oversized trucks which are also referred to as superloads, abnormal loads, or large trucks. If roundabouts are not properly designed to accommodate these oversized trucks, they can damage the elevated parts of intersections

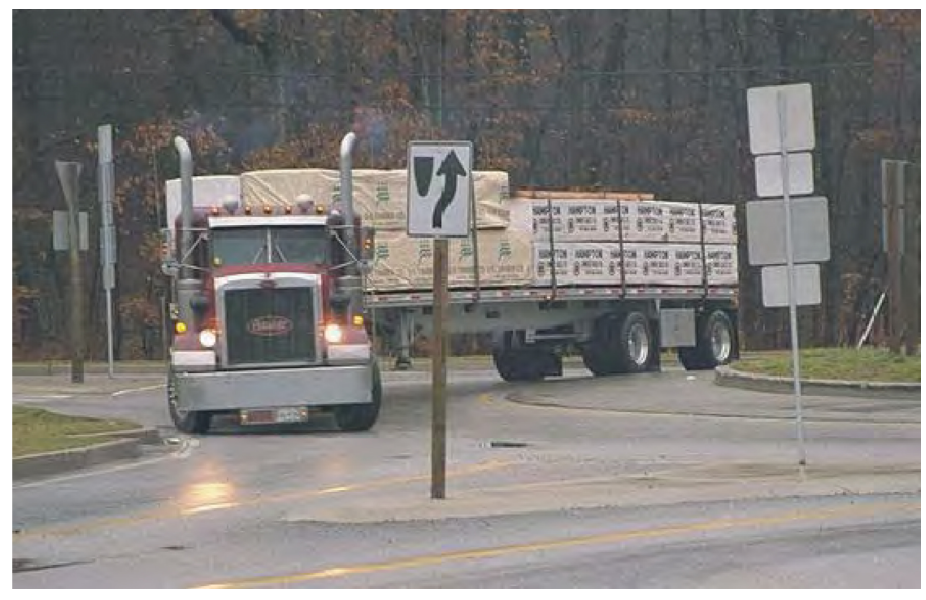

Figure 2. Truck using a truck apron at roundabout. Source: Roundabouts: An informational guide, second edition [6].

Table 1. Roundabout inscribed circle diameter range based on roundabout type and design vehicle.

\begin{tabular}{|c|c|c|c|}
\hline $\begin{array}{l}\text { Roundabout } \\
\text { Configuration }\end{array}$ & $\begin{array}{c}\text { Typical } \\
\text { Design Vehicle }\end{array}$ & \multicolumn{2}{|c|}{$\begin{array}{l}\text { Common Inscribed } \\
\text { Circle Diameter Range }\end{array}$} \\
\hline \multirow[t]{2}{*}{ Mini-Roundabout } & SU-30 (SU-9) & 45 to $90 \mathrm{ft}$. & (14 to $27 \mathrm{~m}$ ) \\
\hline & B-40 (B-12) & 90 to $150 \mathrm{ft}$. & ( 27 to $46 \mathrm{~m}$ ) \\
\hline \multirow[t]{2}{*}{ Single-Lane Roundabout } & WB-50 (WB-15) & 105 to $150 \mathrm{ft}$. & (32 to $46 \mathrm{~m}$ ) \\
\hline & WB-67 (WB-20) & 130 to $180 \mathrm{ft}$. & (40 to $55 \mathrm{~m}$ ) \\
\hline \multirow{2}{*}{ Multilane Roundabout } & WB-50 (WB-15) & 150 to $220 \mathrm{ft}$. & $(46$ to $67 \mathrm{~m})$ \\
\hline & WB-67 (WB-20) & 165 to $220 \mathrm{ft}$. & $(50$ to $67 \mathrm{~m})$ \\
\hline \multirow{2}{*}{$\begin{array}{l}\text { Multilane Roundabout } \\
\text { (3 lanes) }\end{array}$} & WB-50 (WB-15) & 200 to $250 \mathrm{ft}$. & (61 to $76 \mathrm{~m}$ ) \\
\hline & WB-67 (WB-20) & 220 to $300 \mathrm{ft}$. & (67 to $91 \mathrm{~m})$ \\
\hline
\end{tabular}

Source: roundabouts: an informational guide, second edition [6]. 
such as center islands, intersection corners, splitter islands, lamp posts, traffic signs, etc. [8]. The potential uses and benefits of roundabouts can be diminished if they cannot accommodate oversized trucks which traverse certain roundabouts once in a while. Some of the oversized truck configurations that are commonly travelled in United States are summarized in Figure 3 and Figure 4.

Traditionally, roundabout geometry is designed based on the design vehicle, which is the largest vehicle that can reasonably be expected for normal use. However, oversized trucks are permit vehicles that use the roadway with a special permit along with escort vehicles; also, their vehicle length and dimensions are significantly larger than the regular trucks. Designing the roundabout geometrics such as center island diameter, entry and exit lanes, circulatory roadway lanes, etc., for oversized trucks can be very expensive and inefficient as the roundabout size increases significantly; further, such designs could negate the benefits of roundabouts which are obtained by slower speeds through compact designs and curves. Therefore, when a roundabout expects oversized truck configurations, the roundabout should not be designed for such configuration, but the design should be adjusted to accommodate such configurations through

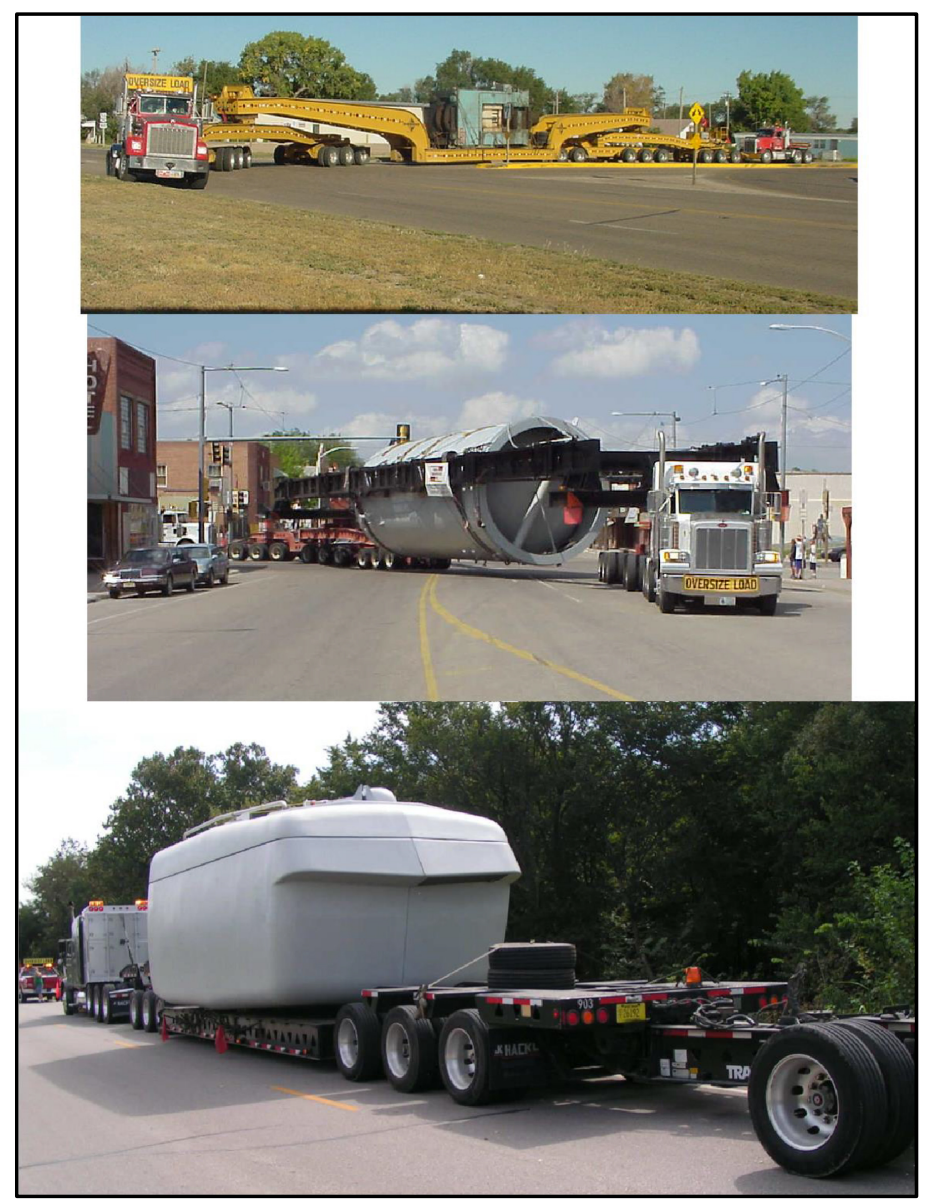

Figure 3. Some oversized truck configurations in United States. Source: Network and design concepts for accommodating large trucks at roundabouts [9]. 


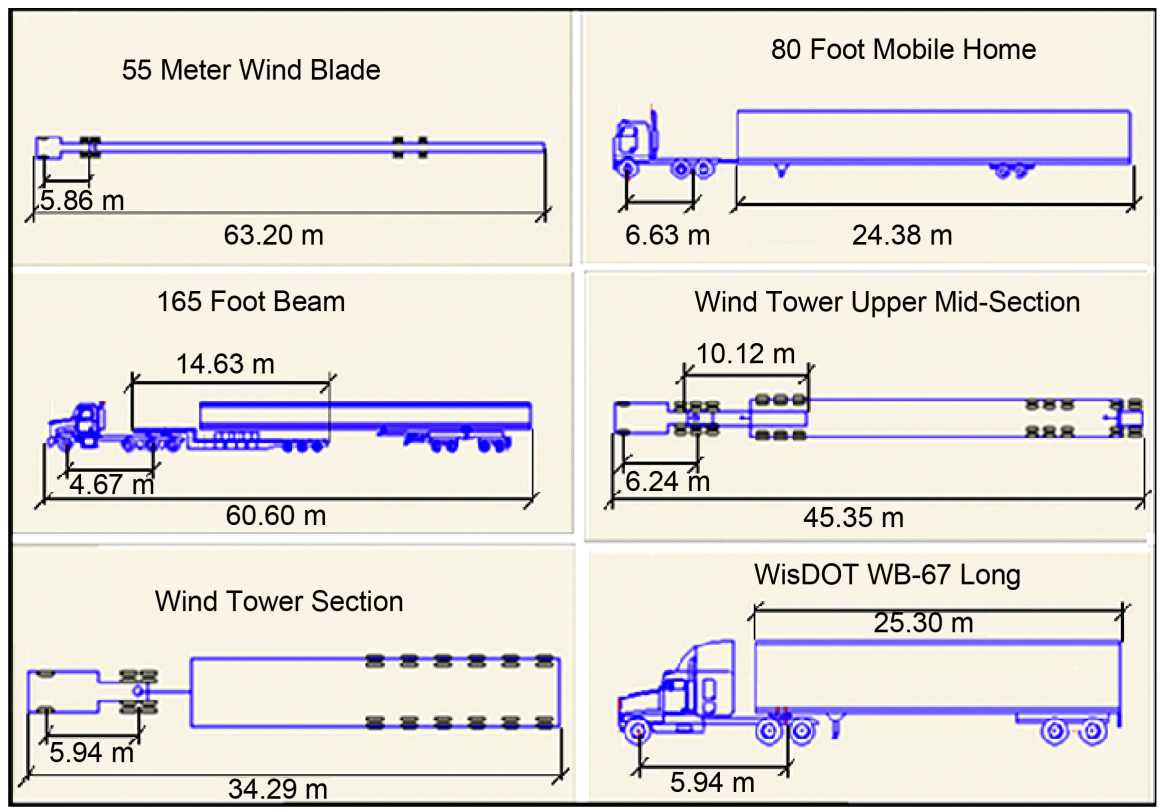

Figure 4. Commonly used oversized truck configurations in United States. Source: Using vehicle simulations to understand strategies for accommodating oversize, overweight vehicles at roundabouts [10].

unique features. Few studies have been conducted on this issue about accommodating oversized trucks at roundabouts.

Some of the accommodation strategies that were practiced around the world and in United States for safely accommodation oversized trucks at roundabouts are [6] [10]-[15]:

1) Constructing fully traversable center islands at roundabouts so oversized trucks can go over them while traversing a roundabout avoiding the need to build bigger roundabouts.

2) Constructing custom center island truck apron and external truck apron based on understanding the expected oversized truck traffic, their movement, and swept path.

3) Allowing the oversized truck traffic to go in the opposite direction of the traffic at roundabout while traversing a left turn so that the need for additional truck apron and/or traversable area would be decreased.

4) Building a straight passage through the center island so the oversized truck traffic which is anticipated to travel always through can be accommodated in the easiest possible way. This straight through passage however has to have gates so the normal vehicles can stay away from using it. Figure 5 illustrates this strategy that is being practiced in Germany.

A comprehensive list of roundabout features to facilitate all the above mentioned oversized truck accommodation strategies are: wider and custom center island truck aprons, need for external truck apron, traversable splitter islands, fully traversable center island, removable signs in a roundabout, and no poles in the swept path area of oversized truck/trucks expected [10] [11] [12] [13]. 


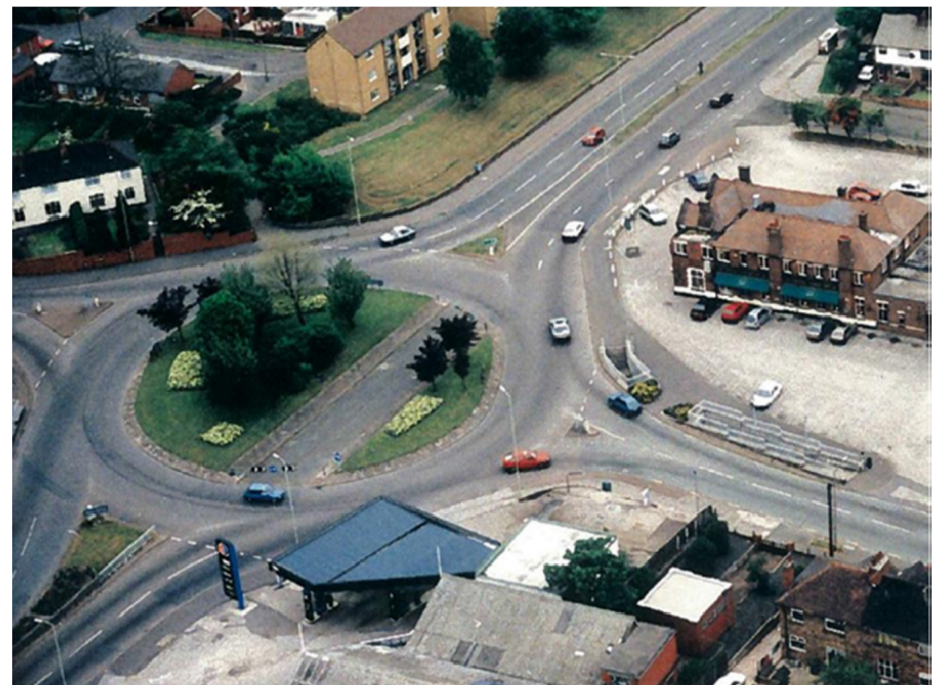

Figure 5. Roundabout with straight through passage for oversized trucks. Source: Unconventional roundabout geometrics for large vehicles or space constraints [15].

\section{Truck Safety at Roundabouts}

The construction and use of roundabouts in United States have significantly increased over the last decade and are likely to rise considering the operational, capacity, and safety benefits. Number of roundabouts being constructed recently has increased, and they were also prominent on high-speed roads with considerable truck traffic presenting a new challenge of accommodating these trucks safely [16]. Several experiences in United States and internationally have proven that some of the safety concerns for trucks at roundabouts are truck rollover problems and truck hang-up problems while maneuvering a roundabout.

While one of the major advantages of roundabouts is decreasing the number of overall crashes at the intersections, vehicles may be susceptible to rollover risk if they are installed on high-speed roads with $50 \mathrm{mph}$ or higher speeds. According to Kansas Department of Transportation reports, about half of the truck crashes at roundabouts on high-speed roads were rollovers. Studies conducted in Australia and U.K have also proved that trucks are susceptible to rollover crashes at roundabouts; some of the contributing factors include high speed approaches, small entry deflection curve, better visibility at a roundabout intersection encouraging higher speeds, sudden grade/super elevation changes, and significant decrease in curve radius within the roundabouts [17] [18]. Fully loaded semi-trailers have their center of gravity higher than the empty ones, and the geometric layout of roundabouts can be risky for high center of gravity vehicles at roundabouts even at lower speeds [19]. Hou and Ahmadian [19] conducted a study analyzing the effect of truck configurations on the roll stability of commercial trucks in roundabouts in urban settings, and found that trucks traversing the truck aprons can increase the risk of truck rollover crashes. Further, roll stability was found highest in single-unit truck; WB-67 and combination of 
tractor with 40-foot trailer configurations can have higher rollover risks at roundabouts. Tarko et al. [16] have studied the rollover propensity of semi-trailers at existing roundabouts and tight curves during daytime and nighttime conditions; the study found that rollover propensity of semitrailers is low during night times compared to day times, because the drivers were observed driving more cautiously in nighttime conditions.

Apart from rollover risk, one other major issue specifically for low clearance trucks at roundabouts is truck hang-up problem where the undercarriage of low clearance trucks damage curbs and truck aprons of a roundabout. Low clearance trucks hang-up problem is not only an issue at roundabouts, but also elsewhere at many locations in the traffic stream [20]. Truck hang-ups results in vehicular delay, minor damage to vehicle undercarriage, damage to roadway infrastructure, and sometimes crashes [21]. Godavarthy and Russell [22] simulated numerous number of low clearance trucks at various roundabout settings using AutoTURN 3D and TORUS software and determined that a four-inch and three-inch truck-apron heights that were traditionally used at single lane roundabouts were not suitable for accommodating lowboy vehicle trailers; however, a two-inch truck apron height seemed feasible. At a double lane roundabout, a three-inch truck apron height seemed feasible with lowboy trailers [22].

\section{Motor Carrier (Truck Driver) Perspective of Roundabouts}

While roundabouts are relatively new to United States, they were designed to accommodate trucks and large trucks safe and efficiently. Even with design features of roundabouts suitable for truck accommodation, there have been some common problems and truck navigating issues observed at roundabouts [23]. Therefore, it is important to study truck navigation and accommodation issues of a roundabout from a truck driver perspective. American Trucking Research Institute and Kansas State University conducted surveys with commercial truck drivers negotiating roundabouts and 60 survey responses were received from trucking agencies [9] [23]. Some of the unique and common problems mentioned by truck drivers at roundabouts are [9] [23]:

1) Roundabouts being too small for larger trucks accommodation,

2) Instances of truck trailer encroaching into the center island,

3) Curbs being a hindrance for large trucks while making turns,

4) Truck trailers drifting and using second lane which can cause potential crashes and safety concerns,

5) Difficulty accelerating quickly to merge into traffic,

6) Passenger vehicle drivers not educated enough to give needed room for truck's tractor trailer,

7) Elevated and sloping curbs causing truck hang-up problem,

8) Blind spot being created on the right side of the truck.

Among the approach, circulatory roadway, and departure for roundabouts, most of the commercial truck drivers responded circulatory roadway being a se- 
rious problem for maneuvering. The study concluded that roundabouts expecting trucks or larger trucks should need larger roundabout circumferences, more passenger driver education, and a re-evaluation of roundabout design.

\section{Conclusions}

This study synthesized the research and knowledge of truck accommodation at roundabouts by synthesizing various research studies, reports, and articles; various subject areas such as roundabout designs for trucking activity, roundabout designs and accommodation strategies for specialized trucking activity such as oversized trucks, truck safety at roundabouts, and motor carrier perspective of trucking at roundabouts have been analyzed and relevant knowledge has been synthesized. This synthesis can be useful to researchers, designers, planners, and decision makers to determine effective ways to address specific trucking related issues at a roundabout.

While most of the trucking issues at roundabouts have been addressed through various studies, their implementation and usefulness is minimal since all the latest research and roundabout design solutions are not incorporated in the roundabout design guides, highway design documents and manuals; specifically, because these guides and documents were old and outdated. Therefore, there is a great need to include the updated standards and roundabout designs in the upcoming roundabout design guides, and other design documents.

\section{References}

[1] Persaud, B., Retting, R., Garder, P. and Lord, D. (2001) Safety Effect of Roundabout Conversions in the United States: Empirical Bayes Observational Before-After Study. Transportation Research Record, 1-8. https://doi.org/10.3141/1751-01

[2] Mandavilli, S., Rys, M.J. and Russell, E.R. (2008) Environmental Impact of Modern Roundabouts. International Journal of Industrial Ergonomics, 38, 135-142. https://doi.org/10.1016/j.ergon.2006.11.003

[3] Godavarthy, R. and Russell, E. (2015) Integrating Roundabouts with Freight Roadway Networks. Smart Grid and Renewable Energy, 6, 293-302. https://doi.org/10.4236/sgre.2015.610024

[4] Godavarthy, R., Mirzazadeh, B., Russell, E. and Landman, D. (2016) Roundabout's Impact on Nearby Businesses. Journal of Transportation Technologies, 6, 181-191. https://doi.org/10.4236/jtts.2016.64018

[5] Russell, E., Landman, E. and Godavarthy, R. (2012) A Study of the Impact of Roundabouts on Traffic Flows and Business. Report No. K-TRAN: KSU-09-10, Kansas Department of Transportation.

[6] Rodegerdts, L., Bansen, J., Tiesler, C., Knudsen, J., Myers, E., Johnson, M., Moule, M., Persaud, B., Lyon, C., Hallmark, S., Isebrands, H., Crown, R.B., Guichet, B. and O’Brien, A. (2010) NCHRP Report 672: Roundabouts: An Informational Guide. 2nd Edition, Transportation Research Board, Washington DC.

[7] Waddell, E., Gingrich, M.A. and Lenters, M. (2009) Trucks in Roundabouts: Pitfalls in Design and Operations. ITE Journal, 40-45.

[8] Petru, J. and Zaman, K. (2013) Analysis of Roundabout Intersections on Routes of 
Abnormal Loads. Recent Advances in Urban Planning and Construction, 47-53.

[9] Godavarthy, R.P. (2012) Network and Design Concepts for Accommodating Large Trucks at Roundabouts. PhD Dissertation, Kansas State University, Manhattan.

[10] Godavarthy, R., Russell, E. and Landman, D. (2016) Using Vehicle Simulations to Understand Strategies for Accommodating Oversize, Overweight Vehicles at Roundabouts. Transportation Research Part A, 87, 41-50. https://doi.org/10.1016/j.tra.2016.03.002

[11] Russell, E.R., Landman, E. and Godavarthy, R. (2013) Accommodating Oversize/Overweight Vehicles at Roundabouts. Report No. K-TRAN: KSU-10-1, Kansas Department of Transportation.

[12] Russell, E.R., Landman, D. and Godavarthy, R. (2013) Key Findings and Conclusions for the Study: Accommodating Oversize/Overweight Vehicles at Roundabouts. 2013 Conference and Exhibition of the Transportation Association of Canada-Transportation: Better-Faster-Safer, Transportation Association of Canada.

[13] Russell, E.R., Landman, D. and Godavarthy, R. (2013) Study of Accommodating Oversize, Overweight Vehicles at Roundabouts. 92nd Transportation Research Board Annual Meeting, Transportation Research Board, Washington DC.

[14] Godavarthy, R.P., Russell, E.R. and Landman, D. (2012) Accommodating Oversize/Overweight Vehicles at Roundabouts: Survey Results and Preliminary Designs. Research in Agricultural \& Applied Economics.

[15] Gazzarri, A., Pratelli, A., Souleyrette, R.R. and Russell, E.R. (2014) Unconventional Roundabout Geometrics for Large Vehicles or Space Constraints. Proceedings of the Fourth International Conference on Roundabouts, Seattle, Washington DC.

[16] Tarko, A., Hall, T., Romero, M. and Jimenez, C.G. (2016) Evaluating the Rollover Propensity of Trucks-A Roundabout Example. Accident Analysis and Prevention, 91, 127-134. https://doi.org/10.1016/j.aap.2016.02.032

[17] Arndt, O.K. and Troutbeck, R.J. (1998) Relationship between Roundabout Geometry and Accident Rates. Transportation Research Board, National Research Council, Washington DC.

[18] Geometric Design of Roundabouts (2007) Design Manual for Roads and Bridges. U.K. Highways Agency.

[19] Hou, Y. and Ahmadian, M. (2015) Effects of Commercial Truck Configuration on Roll Stability in Roundabouts. SAE Technical Paper 2015-01-2741. https://doi.org/10.4271/2015-01-2741

[20] Eck, R.W. and Kang, S. (1991) Low-Clearance Vehicles at Rail-Highway Grade Crossings: An Overview of the Problem and Potential Solutions. In: Transportation Research Record, National Research Council, Washington DC, 27-35.

[21] French, L., Clawson, A. and Eck, R.W. (2003) Development of Design Vehicles for the Hangup Problem. Transportation Research Board Annual Meeting: Compendium of Papers, Washington DC.

[22] Godavarthy, R.P. and Russell, E.R. (2015) Low-Clearance Truck's Vertical Requirements at Roundabouts. Journal of Transportation Technologies, 5, 214-222. https://doi.org/10.4236/jtts.2015.54020

[23] Park, L. and Pierce, D. (2013) Roundabouts and the Accommodation of Large Trucks: A Motor Carrier Perspective. Transportation Research Record, 10-13. https://doi.org/10.3141/2388-02 